\title{
Acad. Solomon Marcus at 85 Years (A Selective Bio-bibliography)
}

\author{
F. G. Filip (Editor in Chief of IJCCC), \\ I. Dzitac (Associate Editor in Chief of IJCCC)
}

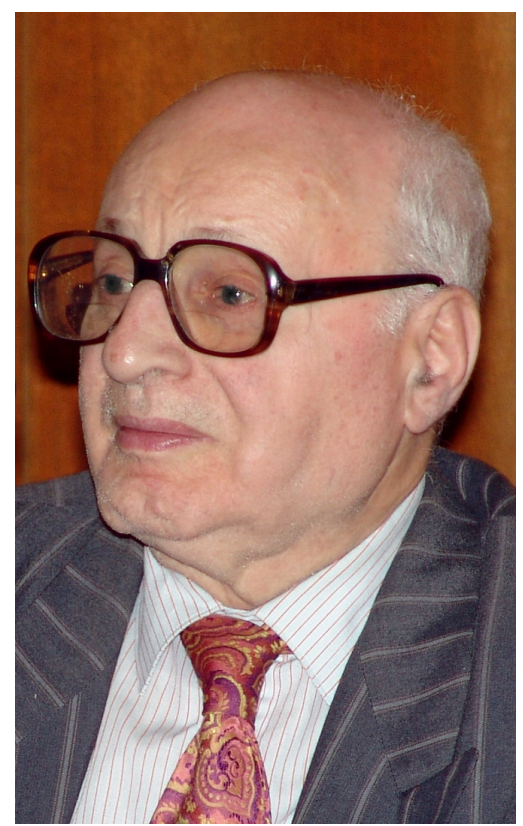

Professor Solomon Marcus is one of the seniors of the Romanian science and culture, with a tremendously diverse and intensive activity, with numerous, fundamental, and many times pioneering contributions to mathematics, mathematical linguistics, formal language theory, semiotics, education, and to other areas, with an impressive internal and international impact and recognition, since several decades very actively involved in the scientific and cultural life - and still as active as ever at his age. That is why the short presentation below is by no means complete, it is only a way to pay our homage to him at his 85th birthday anniversary.

We are honored and we thank to professor Solomon Marcus for having the kindness to publish, in the first issue of this journal, an article occasioned by the Moisil centenary ${ }^{1}$.

\section{Biography and General Data}

Born at March 1, 1925, in Bacău, Romania. Elementary school and high school in Bacău, classified the first at the school-leaving examination ("bacalaureat"), in 1944. Faculty of Science, Mathematics, University of Bucharest, 1945-1949. Assistant professor since 1950, lecturer since 1955, associate professor since 1964, and professor since 1966. Professor Emeritus since 1991, when he retired. All positions held in the Faculty of Mathematics, University of Bucharest. PhD in Mathematics in 1956 (with the thesis about "Monotonous functions of two variables"), State Doctor in Sciences in 1968, both at the University of Bucharest. Corresponding Member of Romanian Academy since April 1993, and Full Member of the Romanian Academy (Academician) since December 2001.

\footnotetext{
${ }^{1}$ Grigore C. Moisil: A Life Becoming a Myth, International Journal of Computers, Communications \& Control, 1(1),73-79, 2006
} 
Research and teaching in the fields of mathematical analysis, theoretical computer science, measure theory, general topology, linguistics, history and philosophy of mathematics, poetics, semiotics, applications of mathematics to natural and social sciences.

Has published over 50 books, as single author or in collaboration, and over 400 research articles, as well as several hundreds of articles on various cultural topics. Has edited over 40 collective volumes.

More than 250 invited lectures at various universities from Europe, Americas, and Asia.

In his papers and books has solved many open problems in mathematical analysis and has formulated a still larger number of problems and research topics, has introduced new ideas, notions and models, which were addressed and continued by a large number of researchers. Just an example: the contextual grammars he has introduced in 1967-68 are now called Marcus contextual grammars and were subject of many papers and $\mathrm{PhD}$ theses, as well as of two monographs.

Many students and collaborators, a really "contagious" professor and researcher.

Cited and followed by thousand of authors, from Romania and abroad.

His books were reviewed and commented by many personalities, among whom, we mention a few: Emanuel Vasiliu, Mike Holcombe, Sheng Yu, Yehosua Bar-Hillel, Maurice Gross, L. Nebesky, Michel Janot, I.I. Revzin, Ferenc Kiefer, H.P. Edmundson, Ju.A. Sreider, Jacob L. Mey, Carlo Tagliavini, Gr.C. Moisil, Matei Călinescu, Nicolae Manolescu, Sorin Stati, K. Sgallova, P. Sgall, Gabriela Melinescu, Jean-Marie Klinkenberg, Virgil Nemoianu, Adrian Marino, Miron Nicolescu, Alexandru Ivasiuc, Wladimir Krysinski, Mircea Mihăieş, Şerban Cioculescu, Eugen Simion, Constantin Negoiţă, Tudor Octavian, Dinu Flamând, Stelian Tănase, Alin Teodorescu, Mircea Scarlat, Smaranda Vultur, Cristian Calude, Gheorghe Păun, Tudorel Urian, Paul Cernat, Irina Mavrodin, Rosa del Conte, Jean-Pierre Descles, Umberto Eco, Marius Iosifescu, Roman Jakobson, Gheorghe Mihoc, Octav Onicescu, Cesare Segre, Gheorghe Tomozei, Iorgu Iordan, Constanţa Buzea, Cornel Ungureanu, Bogdan Suceavă, Basarab Nicolescu, Alexandru T. Balaban, Mihai Zamfir, and many others.

Member of the editorial board of over three dozens of professional journals.

Among the numerous honors received, we recall: Doctor Honoris Causa of the Universities of Bacău, Constanţa, and Craiova. Vice President of the International Association for Semiotic Studies (19891999). Honorary President of the Balkan Semiotic Society (since 2001). Member of the Executive Committee of the International Association for Semiotic Studies. Honorary Member of the International Association for Visual Semiotics. Honorary Member of the Toronto Semiotic Circle, of Como (Italy) Semiotic Circle and of the Hungarian Semiotic Society. Honorary member of the Romanian Mathematical Society. Permanent Invited Professor, Sao Paulo Catholic University. Member of the Romanian National Mathematical Committee. Member of the leading Council of the Romanian Linguistic Society. Member of the Romanian Union of Writers and Member (1990-1995) of the leading Council of this Union. Vice-president of the Romanian Semiotic Society. Member of the Romanian Committee for the Club of Rome. Honorary member of the Society Eratosthene, Switzerland.

He has also received many prizes, in Romania and abroad.

With various occasions, special issue of journals and collective volumes were devoted to him. Here are some of them: The International Journal of Computer Mathematics (Great Britain) and Revue Roumaine de Mathematiques Pures et Appliquées devoted some of their issues in 1985 to his 60th anniversary, while two collective volumes were dedicated to his 70th anniversary, in 1995, Mathematical Aspects of Natural and Formal Languages, World Scientific, Singapore, 1994, and Mathematical Linguistics and Related Topics, Ed. Academiei, Bucharest, 1995. In the year 2000, two volumes were dedicated to his 75th anniversary: Finite vs Infinite. An Eternal Dilemma, Springer, London, and Recent Topics in Mathematical and Computational Linguistics, Ed. Academiei, Bucharest. In the year 2005, volume 64, numbers 1-4 of Fundamenta Informaticae were published as a "Special issue in Honor of the 80th Birthday of Professor Solomon Marcus", with papers by 70 authors from 16 countries. 


\section{Books, Authored or Co-authored}

1. Lingvistica matematică. Modele matematice în lingvistică. Ed. Didactică şi Pedagogică. Bucureşti, 1963.

2. Gramatici şi automate finite. Ed Academiei, Bucureşti, 1964.

3. Analiza matematică. Vol. I. Ed. Didactică şi Pedagogică, Bucureşti, 1st edition 1962, 2nd edition 1963, 3rd edition 1966, 4th edition 1971, 5th edition 1980 (in collab. with M. Nicolescu and N. Dinculeanu).

4. Lingvistica matematică (2nd edition, revised and completed with 4 new chapters). Ed. Didactică şi Pedagogică, Bucureşti, 1966.

5. Introducere în lingvistica matematică. Ed. Ştiinţifică, Bucureşti, 1966 (in collab. with E. Nicolau and S. Stati)

6. Noţiuni de analiză matematică. Originea, evoluţia şi semnificaţia lor. Ed. Ştiinţifică, Bucureşti, 1967.

7. Limbaj, logică, filozofie. Ed. Ştiinţifică, Bucureşti, 1968 (in collab. with Al. Boboc, Gh. Enescu, C. Popa, and S. Stati).

8. Analiza matematică. Vol. II. Ed. Didactică şi Pedagogică, Bucureşti, 1st edition 1966, 2nd edition 1971, 3rd edition 1980 (in collab. with M. Nicolescu and N. Dinculeanu).

9. Introduction mathematique a la linguistique structurale. Dunod, Paris, 1967.

10. Algebraic Linguistics; Analytical Models. Academic Press, New York, 1967.

11. Poetica matematică. Ed. Academiei, Bucureşti, 1970.

12. Teoretiko-mnozestvennye modeli jazykov. Ed. Nauka, Moscova, 1970 (translation of the first five chapters of book 10 and of the last chapter of book 9).

13. Algebraicke modely jazyka. Ed. Academia, Prague, 1969 (translation in Czech of book 4, and of a part of book 2).

14. Introduzione alla linguistica matematica. Casa editrice Riccardo Patron, Bologna, 1970 (revised and completed translation of book 5; in collab. with E. Nicolau and S. Stati).

15. Mathematische Poetik. Ed. Academiei, Bucureşti - Athenaum-Verlag, Frankfurt am Main, 1973 (revised and completed translation of book 11).

16. Matematicka Poetika. Ed. Nolit, Belgrad, 1974 (revised and completed Serbo-Croatian translation of book 11).

17. Din gândirea matematică românească. Ed. Ştiinţifică şi Enciclopedică, Bucureşti, 1975.

18. Semiotica folclorului. Abordare lingvistico-matematică. Ed. Academiei, Bucureşti, 1975 (coauthor).

19. Matematicka analyza ctena podruhe. Ed. Academia, Prague, 1976 (revised and completed Czech translation of book 6).

20. A nyelvi szepseq matematikaja. Ed. Gondolat, Budapesta, 1977.

21. Metode distribuţionale algebrice în lingvistică. Ed. Academiei, Bucureşti, 1977 (coauthor).

22. La semiotique formelle du folklore. Approche linguistico-mathematique. Ed. Klincksieck, Paris Ed. Academiei, Bucureşti, 1978 (revised and completed translation of book 18; co-author).

23. Introduccion en la linguistica matematica. Ed. Teide. Barcelona, 1978 (revised and completed Spanish translation of book 5).

24. Semne despre semne. Ed. Ştiinţifică şi Enciclopedică, Bucureşti, 1979. 
25. Contextual ambiguities in natural \& artificial languages. Vol. 1, Communication and Cognition, Ghent, Belgium, 1981 (revised and completed translation of a part of book 21).

26. Snmeia gia ta snmeia. Ed. Pneumatikos, Atena, 1981 (Greek translation of book 24).

27. Metode matematice în problematica dezvoltării. Ed. Academiei, Bucureşti, 1982 (co-author).

28. Gândirea algoritmică. Ed. Tehnică, Bucureşti, 1982.

29. Semiotica matematică a artelor vizuale. Ed. Ştiinţifică şi Enciclopedică, Bucureşti, 1982 (coordinator and co-author).

30. Simion Stoilow. Ed. Ştiinţifică şi Enciclopedică, Bucureşti, 1983 (in collab. with Cabiria Andreian Cazacu).

31. Paradoxul. Ed. Albatros, Bucureşti, 1984.

32. Timpul. Ed. Albatros, Bucureşti, 1985.

33. Artă şi ştiinţă. Ed. Eminescu, Bucureşti, 1986.

34. Analiza matematică. Vol. II, Univ. Bucureşti, 1986 (co-author).

35. To Paradocso. Ed. Pneumatikos, Atena, 1986 (Greek version of book 31).

36. Şocul matematicii. Ed. Albatros, Bucureşti, 1987.

37. Moduri de gândire. Colecţia "Ştiinţa pentru toţi", Ed. Ştiinţifică şi Enciclopedică, Bucureşti, 1987.

38. Provocarea ştiinţei. Seria "Idei contemporane", Ed. Politică, Bucureşti, 1988.

39. Invenţie şi descoperire. Ed. Cartea Românească, 1989.

40. Analiza matematică. Materiale pentru perfecţionarea profesorilor de liceu III. Universitatea din Bucureşti, Facultatea de Matematică, Bucureşti, 1989 (co-author).

41. Dicţionar de Analiză Matematică. Ed. Ştiinţifică şi Enciclopedică, Bucureşti, 1989 (co-author).

42. Controverse în ştiinţă şi inginerie. Ed. Tehnică, Bucureşti, 1991.

43. Language, Logic, Cognition and Communication; A Semiotic, Computational and Historical Approach. Report 9/96. Grup de Recerca en Linguistica Matematica i Enginyeria del Llenguatge. Reports Universitat Rovira i Virgili, Tarragona, Spain, 1996.

44. Matematica, manual pentru clasa a IX-a, licee teoretice specializarea filologie (in colab. with Mihaela Singer). Ed. Sigma, Bucureşti, 1999; 2nd edition, 2000.

45. Matematica, manual pentru clasa a XII-a (in colab. with P. Alexandrescu, M. Radulescu, S. Radulescu). Ed. Paralela 45, Bucureşti - Piteşti, 2002.

46. Jocul ca libertate. Ed. Scripta (Colecţia ludică), Bucureşti, 2003.

47. Mathematics in Romania. CUB Press 22, Baia Mare, 2004.

48. Intâlnirea extremelor. Scriitori în orizontul ştiinţei. Ed. Paralela 45, Bucureşti - Piteşti, 2005.

49. Paradigme universale. Ed. Paralela 45, Piteşti - Bucureşti, 2005.

50. Paradigme universale II. Pornind de la un zâmbet. Ed. Paralela 45, Piteşti - Bucureşti, 2006.

51. Paradigme universale III. Jocul. Ed. Paralela 45, Piteşti - Bucureşti, 2007.

52. Words and Languages Everywhere. Polimetrica Academic Publisher, Milano, 2007.

53. Solomon Marcus (protagonist): Educaţia în spectacol. Spandugino Publ. House., Bucureşti, 2010. 